\title{
INVASIVE TRICHOSPORON CUTANEUM INFECTION IN AN INFANT WITH WILMS' TUMOR
}

\author{
Ana Maria Rabelo de Carvalho ${ }^{1}$; Luciana Resende Bandeira de Melo²; Vera Lúcia Moraes ${ }^{3}$; Rejane Pereira Neves ${ }^{1 *}$ \\ ${ }^{1}$ Departamento de Micologia, Centro de Ciências Biológicas, Universidade Federal de Pernambuco, Recife, PE, Brasil; ${ }^{2} \mathrm{Hospital}$ \\ Universitário Oswaldo Cruz, Pronto de Socorro Cardiológico, Recife, PE, Brasil; ${ }^{3}$ Hospital Universitário Oswaldo Cruz, Centro \\ de Oncologia, Recife, PE, Brasil.
}

Submitted: September 27, 2007; Returned to authors for corrections: November 04, 2007; Approved: November 16, 2007.

\begin{abstract}
Fungal infections are increasingly being reported in immuno-compromised patients. In this study we report a case of systemic Trichosporon cutaneum infection in an infant with Wilms' tumor. This is the first time that an invasive infection for T. cutaneum has been reported in a Wilms' tumor patient.
\end{abstract}

Key words: Fungal infections; Trichosporon cutaneum; an infant; diagnosis; Wilms' tumor.

Deep systemic Trichosporon infection has been observed in association with hematologic malignancy, central venous catheter use, broad-spectrum antibiotics, neutropenia, receiving of anti-neoplastic chemotherapy, immunosuppressive therapy and diminished immune function of various causes $(11,15)$. Though uncommon, trichosporonosis caused by T. cutaneum is frequently fatal $(6,12,13)$. Immuno-compromised hosts are particularly at risk and invasive infection rapidly involves various organs such as the lungs, the kidneys, and the spleen. Cutaneous lesions, a sign of disseminated infection, are also probable $(7,15)$.

Wilms' tumor is the most common malignant renal neoplasm in an infant $(3,8)$. The tumor commonly presents as an asymptomatic abdominal mass in children between 2 and 4 years old. Due to the ongoing success of clinical trials the overall survival rate is as high as $85 \%$ (5). However, opportunistic fungal infections are still a leading cause of death in immunosuppressed patients undergoing intensive chemotherapy $(1,9)$.

A 3-year-old infant with Wilms' tumor was admitted for treatment to the Osvaldo Cruz University Hospital, Recife, Brazil in 2006. The patient suffered from severe neutropenia and was being treated for a fever with broad-spectrum antibiotics empirically administered.

Three venous blood samples were collected aseptically by venipuncture into VACUTAINER ${ }^{\circledR}$ tubes using EDTA anticoagulant on three consecutive days. They were processed by standard methods for mycological diagnosis (direct examination and isolation in culture) at Medical Mycology Laboratory, Federal University of Pernambuco, Recife.

Direct examination was performed on fresh samples (without clarification and staining) and for isolation, spreading was performed on the surface of Sabouraud agar (Difco) with $0.5 \mathrm{mg}$ of yeast extract/L and $50 \mathrm{mg}$ chloranphenicol/L, and then incubated at between $30^{\circ} \mathrm{C}$ and $35^{\circ} \mathrm{C}$ in an aerobic atmosphere for 10 days. After the isolation and culture purification, taxonomic identification was achieved using the recognized macroscopic, microscopic, physiologic and VITEK 120 test methods $(4,10)$.

Diagnostic identification was based on both the presence of septation of hyaline hyphae in the three samples of blood and the isolation of the causal agent $T$. cutaneum in pure culture in all samples. Microscopic examination showed hyaline, septate hyphae with fragment into arthroconidia cylindrical to ellipsoidal, 2 to $4 \times 3 \mu$. Blastoconidia were also observed. T. cutaneum colonies are moderately expanding, cerebriform, shiny, not becoming farinose with age, with broad and fissured marginal zones (Fig. 1). T. cutaneum lacks the ability to ferment carbohydrates. It assimilates glucose, galactose, sucrose, maltose and lactose, which distinguishes it from other members of the genus Trichosporon. Potassium nitrate is not utilized, and arbutin is split. The organism was identified as T. cutaneum according to the criteria described by Barnett et al. (2) and Hoog et al. (4).

*Corresponding Author. Mailing address: R. José Paraíso, 135/01, Boa Viagem, Recife-PE, Brasil. 51030-390. Fax: (+5581) 2126-8482. E-mail: rejadel@yahoo.com.br 


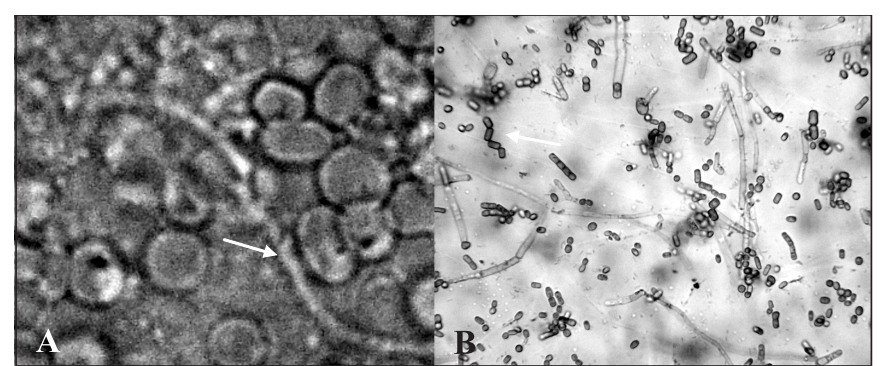

Figure 1. Direct examination revealed hyphae hyaline-1000x (A) characteristic microscopy of Trichosporon cutaneum 400x (B).

The strain has been maintained under mineral oil (number 5397) at the internationally recognized URM Culture Collection of Department of Mycology, Federal University of Pernambuco, Brazil.

T. cutaneum a saprophytic fungal organism normally found in the soil, is increasingly being recognized as a cause of lifethreatening systemic illness in immunosuppressed patients $(7$, 14). Disseminated T. cutaneum infection, the most significant pathogen in the genus Trichosporon, has a poor prognosis. This report underscores the importance of this infection as a severe condition which is usually fatal when associated with pre-existing conditions such as cancer.

\section{RESUMO}

\section{Infecção invasiva por Trichosporon cutaneum em um infante com tumor de Wilms}

As infecções fungicas estão sendo relatadas cada vez mais em pacientes imunocomprometidos. Neste estudo nós relatamos um caso de infecção sistêmica por Trichosporon cutaneum em um infante com tumor de Wilms. Esta é a primeira vez que uma infecção invasiva por T. cutaneum é relatada em paciente com tumor de Wilms.

Palavras-chave: Infecções fúngicas; Trichosporon cutaneum; em infantil; diagnóstico; Tumor de Wilms.

\section{REFERENCES}

1. Ahmed, H.U.; Arya, M.; Tsiouris, A.; Sellaturay, S.V.; Shergill, I.S.; Duffy, P.G.; Mushtaq, I. (2007). An update on the management of Wilms' tumour. Eur. J. Surg. Oncol., 20: 1-8.

2. Barnett, J.A.; Paine, R.W.; Yarrow, D. (2000). Yeasts: Characteristics and Identification. Cambridge University Press, Cambridge.

3. Chang, S.E.; Kim, K.J.; Lee, W.S.; Choi, J.H.; Sung, K.J.; Moon, K.C.; Koh, J.K. (2003). A case of Trichosporon cutaneum folliculitis and septicaemia. Clin. Exp. Dermatol., 28: 37-38.

4. De Hoog, G.S.; Guarro, J.; Gene, J.; Figueras, M.J. (2000). Atlas of clinical fungi. The Netherlands, Centraalbureau voor Schimmelcultures, Universitat Rovira i Virgili, Utrecht/Réus.

5. Ebb; D.H.; Green; D.M.; Shamberger, R.C.; Tarbell, N.J. (2005). Solid tumors of childhood. In: DeVita, V.T, Hellman, S., Rosenberg, S.A.(eds). Cancer principles and practice of oncology. LippincottWilliams \& Wilkins, Philadelphia, p.1898-1938.

6. Evans, H.L.; Kletzel, M.; Lawson, R.D.; Frankel, L.S.; Hopfer, R.L. (1980). Systemic mycosis due to Trichosporon cutaneum: a report of two additional cases. Cancer, 45: 367-371.

7. Girmenia, C.; Pagano, L.; Martino, B.; D’antonio, D.; Fanci, R.; Specchia, G. (2005). Invasive Infections Caused by Trichosporon Species and Geotrichum capitatum in Patients with Hematological Malignancies: a Retrospective Multicenter Study from Italy and Review of the Literature, J. Clin. Microbiol., 43: 1818-1828.

8. Higgins, E.M.; Layton, D.M.; Arya, R.; Salisbury, J.; du Vivier, A.W.P. (1994). Disseminated Trichosporon beigelil infection in an immunosuppressed child. J. Royal Soc. Med., 87: 292-293.

9. Khayyata, S.; Grignon, D.J.; Aulicino, M.R.; Al-Abbadi, M.A. (2007). Metanephric adenoma vs. Wilms' tumor: a report of 2 cases with diagnosis by fine needle aspiration and cytologic comparisons. Acta Cytol., 51: 464-467.

10. Lacaz, C.S.; Porto, E. (2002). Tratado de Micologia Médica. Sarvier, São Paulo.

11. Larone, D.H. (2002). Medically Important Fungi - A Guide to Identification. ASM Press, New York.

12. Morimoto, S.; Shimazaki, C.; Goto, H.; Hirata, Y.; Tatsumi, T.; Yamagata, N. (1994). Trichosporon cutaneum fungemia in patients with acute myeloblastic leukemia and measurement of serumdarabinitol, Candida antigen (CAND-TEC), and $\beta$-d-glucan. J. Ann. Hematol., 68: 159-161.

13. Nishimura, S.K.; Akiyama, H.; Saku, K.; Kashiwa, M.; Mori, S.; Tanikawa, S.(1998). Invasive infection due to Trichosporon cutaneum in patients with hematologic malignancies. Am. Cancer Soc., 82: 3484-3487.

14. Rivera, R.; Ayten, C. (1974). Trichosporon sepsis and leukemia. Canncer, 36: 1106-1110.

15. Rojas, F.M.; Magdalena, G.G.(2004). Hongos levaduriformes en neonatos. Frecuencia y sensibilidad antifúngica. Comunicaciones científicas y tecnológicas. Universidad National del Nordeste. 